ISSN: 2302-8556

\title{
Pengaruh Partisipasi Anggaran, Penekanan Anggaran, dan Rencana Kompensasi Terhadap Senjangan Anggaran
}

\author{
I Made Sutanaya ${ }^{1}$ \\ Maria M. Ratna Sari \\ ${ }^{1}$ Fakultas Ekonomi dan Bisnis Universitas Udayana (Unud), Bali, Indonesia \\ e-mail: denpasarfc@ @uest-hotels.com/Tlp: 085361125704 \\ ${ }^{2}$ Fakultas Ekonomi dan Bisnis Universitas Udayana (Unud), Bali, Indonesia
}

\begin{abstract}
ABSTRAK
Penelitian ini bertujuan untuk mengetahui pengaruh partisipasi anggaran, penekanan anggaran dan rencana kompensasi pada senjangan anggaran pada Hotel bintang 4 di Kabupaten Badung. Penelitian ini dilakukan pada 62 Hotel Berbintang 4 yang tersebar di Kabupaten Badung. Sampel yang digunakan dalam penelitian ini adalah sebanyak 47 responden dengan menggunakan metode Purposive sampling. Teknik analisis data yang digunakan dalam penelitian ini adalah analisis regresi linear berganda. Hasil penelitian ini menunjukan bahwa partisipasi anggaran, penekanan anggaran dan rencana kompensasi berpengaruh positif dan signifikan pada senjangan anggaran. Hal ini menunjukkan bahwa meningkatnya partisipasi anggaran, penekanan anggran dan rencana kompensasi dalam penentuan anggaran, maka cenderung akan meningkatkan terjadinya senjangan anggaran.

Kata kunci: Partisipasi anggaran, penekanan anggaran, rencana kompensasi, senjangan anggaran
\end{abstract}

\begin{abstract}
This study aims to determine the effect of budget participation, budget emphasis and compensation plan on budgetary slack at 4 star Hotel in Badung regency. This research was conducted on 62 Four Star Hotel spread in Badung regency. The sample used in this research is 47 respondents by using purposive sampling method. Data analysis technique used multiple linear regression analysis. The results of this study indicate that budget participation, budget presses dand compensation plans has are positive and significant influence on budget slack. This suggests that increased participation in budgetig, budget presses and compensations will tend to increase the occurrence of budgetary slack.

Keywords: Budget participation, budgeting presses, compensation plans, budget slack
\end{abstract}

\section{PENDAHULUAN}

Memasuki era globalisasi, kondisi persaingan antar perusahaan akan semakin berat dan ketat, salah satunya adalah perusahaan perhotelan. Tantangan perusahaan yang semakin berat menuntut perusahaan melakukan pengendalian manajemen sebagai sarana untuk menetapkan perencanaan, koordinasi dan 
evaluasi jalannya kegiatan perusahaan agar mampu bersaing dengan perusahaan lainnya. Perusahaan harus memiliki manajemen pengelolaan sumber-sumber ekonomis perusahaan secara efektif dan efisien. Kegiatan dikatakan efektif apabila kegiatan mengarah pada pencapaian tujuan dan dikatakan efisien apabila kegiatan dapat dilaksanakan dengan menggunakan sumber dana yang minimum (Nawastri, 2015). Sumber ekonomis perusahaan dan juga alat bantu manajemen dalam melaksanakan operasi perusahaan adalah anggaran.

Damrongsukniwat et al. (2015: 224) menyatakan bahwa anggaran dapat digunakan sebagai pedoman dan alat bantu bagi manajemen dalam melaksanakan operasi perusahaan. Anggaran mempunyai peran sebagai suatu sistem bagi seorang manajer perusahaan atau organisasi terutama pada fungsi perencanaan, fungsi koordinasi dan fungsi pengawasan. Perencanaan adalah melihat ke masa depan, menentukan kegiatan apa yang harus dilakukan untuk mencapai tujuan. Pengendalian adalah melihat ke masa lalu, melihat apa yang senyatanya terjadi dan membandingkannya dengan hasil yang direncanakan sebelumnya. Sebuah organisasi membutuhkan anggaran untuk menerjemahkan keseluruhan strategi kedalam rencana jangka pendek dan jangka panjang (Beuren et al., 2015).

Proses penyusunan anggaran dalam sebuah perusahaan terkadang melibatkan atau memberikan kesempatan kepada bawahan/pelaksana anggaran untuk terlibat dalam proses penyusunan anggaran. Keterlibatan bawahan dalam penyusunan anggaran sangat diperlukan. Hal ini didasarkan pada Agency Theory yang menyatakan bahwa atasan (prinsipal) mendelegasikan kepada bawahan (agent) untuk bertanggungjawab melakukan suatu tugas dan membuat keputusan. 
Prinsipal adalah pemilik atau pemegang saham perusahaan sedangkan agent adalah pengelola atau manajer perusahaan sehingga pada perusahaan perhotelan, manajer hotel diberikan wewenang dalam melakukan penyusunan anggaran oleh direktur hotel. Manajer akan membuat target anggaran yang lebih mudah dicapai dengan cara membuat target anggaran yang rendah pada sisi pendapatan dan mengajukan biaya yang lebih (Raudhiah, 2014). Keterlibatan manajer dalam penyusunan anggaran disebut partisipasi anggaran. Partisipasi anggaran ini diperlukan karena manajer yang lebih mengetahui kondisi langsung bagiannya dibandingkan dengan direktur hotel.

Partisipasi anggaran mengakibatkan timbulnya perilaku individu positif yaitu adanya peningkatan kinerja atas dorongan motivasi oleh penghargaan (reward) yang diberikan perusahaan apabila tercapainya suatu target anggaran, sedangkan perilaku negatif yang mungkin terjadi yaitu terciptanya kesenjangan anggaran (Raghunandan et al., 2012). Senjangan anggaran ini dapat terjadi ketika manajer berupaya untuk mencari cara melindungi diri dari risiko yang mengakibatkan tidak tercapainya target anggaran. Manajer yang tidak mampu mencapai target anggaran, akan menghadapi tekanan dari manajemen pada tingkat yang lebih tinggi, seperti: kehilangan bonus, kepercayaan, bahkan kehilangan pekerjaan sehingga untuk menghindari risiko tersebut, manajer akan menciptakan senjangan anggaran.

Apabila dalam perusahaan perhotelan terdapat keadaan, yaitu anggaran merupakan satu faktor yang paling dominan dalam mengukur kinerja bawahan, kondisi tersebut dinamakan penekanan anggaran. Ketika suatu perusahaan 
perhotelan menggunakan anggaran sebagai salah satu tolok ukur kinerja, maka manajer akan berusaha meningkatkan kinerjanya dengan dua cara yaitu yang pertama, meningkatkan performance, sehingga realisasi anggarannya lebih tinggi daripada yang telah dianggarkan. Cara yang kedua adalah dengan cara membuat anggaran mudah untuk dicapai atau dengan kata lain melonggarkan anggaran dengan suatu cara, misalnya dengan merendahkan target pendapatan dan meninggikan biaya perusahaan, sehingga anggaran tersebut mudah untuk dicapai, dalam hal ini akan menimbulkan senjangan anggaran. Dengan demikian, penekanan anggaran akan menimbulkan senjangan anggaran.

Rencana kompensasi dan bonus juga merupakan faktor yang dapat menciptakan senjangan anggaran. Dampak kompensasi atas target anggaran dengan menyatakan bahwa sering kali, bonus yang didasarkan pada pencapaian dan kelebihan anggaran merupakan elemen penting dari kompensasi manajemen. Pada umumnya, bonus tidak dibayarkan kecuali jika anggaran terpenuhi. Bonus meningkat apabila target anggaran terlampaui, namun bonus tersebut umumnya dibatasi pada tingkatan tertentu. Oleh karena itu, para manajer yang memiliki program bonus akan cenderung berperilaku yang kurang disukai pada akhir periode anggaran dengan menciptakan anggaran yang mudah dicapai untuk mendapatkan bonus ketika target anggaran tercapai.

Senjangan anggaran adalah sebuah ketidakefisienan yang dapat mengurangi nilai perusahaan (Damrongsukniwat, 2015: 244). Perusahaan harus dapat mengkaji ulang mengenai kebijakan target perusahaan terutama terkait dengan anggaran dan juga harus memperhatikan faktor-faktor yang dapat 
menyebabkan senjangan anggaran di perusahaan. Fenomena yang terjadi saat ini menujukkan bahwa tekanan lingkungan dan persingan yang semakin ketat menyebabkan terjadinya senjangan anggaran. Penekanan anggaran, partisipasi anggaran dan rencana kompensasi dinyatakan merupakan faktor-faktor yang mempengaruhi senjangan anggaran (Febrian, 2014).

Penelitian ini dilakukan dengan tujuan yaitu 1) untuk mengetahui pengaruh partisipasi anggaran terhadap senjangan anggaran pada Hotel bintang 4 di kabupaten Badung, 2) untuk mengetahui pengaruh penekanan anggaran terhadap senjangan anggaran pada Hotel bintang 4 di kabupaten Badung, dan 3) untuk mengetahui pengaruh rencana kompensasi terhadap senjangan anggaran pada Hotel bintang 4 di kabupaten Badung.

Landasan teori yang digunakan dalam penelitian ini adalah teori agensi (Agency Theory). Agency Theory merupakan teori yang mempelajari hubungan atau keterkaitan pihak-pihak yang memiliki jalinan hubungan fungsional dan struktural, yaitu antara principal dan agent. Teori keagenan dapat dipandang sebagai model kontraktual antara dua atau lebih orang (pihak), dimana salah satu pihak disebut agent yaitu orang yang diberi kuasa oleh principal, yaitu manajemen yang terdiri dari general manager dan para manajer dari setiap departemen sedangkan principal adalah pemilik (owner) dari hotel. Principal mendelegasikan pertanggungjawaban atas decision making kepada agent, hal ini dapat pula dikatakan bahwa principal memberikan suatu amanah kepada agent untuk melaksanakan tugas tertentu sesuai dengan kontrak kerja yang telah 
disepakati. Wewenang dan tanggung jawab agent maupun principal diatur dalam kontrak kerja atas persetujuan bersama.

Partisipasi anggaran merupakan proses penyusunan anggaran dengan melibatkan kontribusi yang tinggi para manajer dalam melakukan penyusunan anggaran. Perilaku tersebut didasarkan pada Agency Theory yang menjelaskan fenomena apabila owner mendelegasikan wewenang kepada manajer untuk bertanggung jawab melakukan tugas dan membuat keputusan. Masalah yang sering muncul dari adanya keterlibatan manajer tingkat bawah atau menengah dalam penyusunan anggaran adalah timbulnya senjangan anggaran. Hal ini manajer yang ikut berpartisipasi dalam penyusunan anggaran memberikan informasi yang bias kepada owner, padahal manajer memiliki informasi yang dapat digunakan untuk membantu keakuratan anggaran perusahaan. Manajer meninggikan pengeluaran atau menurunkan pendapatan dari yang seharusnya, supaya anggaran mudah dicapai. Tingginya keterlibatan manajer dalam melakukan penyusunan anggaran akan memicu manajer melakukan tindakan yang ingin dicapai dengan menciptakan senjangan anggaran.

Partisipasi anggaran mengakibatkan timbulnya perilaku individu positif yaitu adanya peningkatan kinerja atas dorongan motivasi oleh penghargaan (reward) yang diberikan perusahaan apabila tercapainya suatu target anggaran. Sedangkan perilaku negatif yang mungkin terjadi yaitu terciptanya senjangan anggaran. Upaya manajer untuk mencari cara melindungi diri dari risiko yang mengakibatkan tidak tercapainya target anggaran. Bagi manajer yang tidak mampu mencapai target anggaran tersebut, akan menghadapi tekanan dari 
manajemen pada tingkat yang lebih tinggi, seperti: kehilangan bonus, kepercayaan, bahkan kehilangan pekerjaan. Untuk menghindari risiko tersebut pihak manajer akan menciptakan senjangan anggaran.

Penelitian yang dilakukan oleh Apriyandi (2011) memberikan hasil bahwa partisipasi anggaran berpengaruh terhadap senjangan anggaran. Selanjutnya, penelitian yang dilakukan oleh Erina dan Suartana (2016) memberikan hasil bahwa partisipasi anggaran mempunyai pengaruh positif terhadap senjangan anggaran. Berdasarkan literatur dan hasil penelitian sebelumnya maka dapat dirumuskan hipotesis sebagai berikut:

$\mathrm{H}_{1}$ : Partisipasi anggaran berpengaruh positif terhadap senjangan anggaran.

Apabila kinerja manajer sangat ditentukan oleh anggaran yang telah disusun, maka manajer akan berusaha memperoleh variance yang menguntungkan. Variance yang menguntungkan tersebut diperoleh dengan cara menciptakan Slack (Raudhiah, 2014). Hasil penelitian Karsam (2015) menunjukkan penekanan anggaran yang diterapkan dalam perusahaan akan memicu terjadinya upaya manajer untuk melakukan senjangan anggaran agar anggaran yang telah disusun mudah dicapai dengan cara melonggarkan anggaran. Manajer berusaha memperoleh perbedaan yang menguntungkan dengan cara menciptakan senjangan anggaran untuk mencapai target anggaran.

Faktor penekanan anggaran yang dapat menimbulkan senjangan anggaran juga dijelaskan oleh Lau (2013: 10) bahwa perusahaan yang menggunakan anggaran sebagai satu-satunya pengukur kinerja manajemen, yaitu berdasarkan tercapai atau tidaknya target anggaran akan mendorong manajer untuk 
menciptakan senjangan dengan tujuan meningkatkan prospek kompensasi ke depan. Dengan demikian, jika anggaran dijadikan tolak ukur untuk menilai kinerja manajer, maka akan memicu tindakan bawahan untuk melakukan senjangan anggaran. Dengan tujuan agar anggaran yang ditetapkan mudah dicapai, sehingga manajer memperoleh penghargaan jika pencapaian anggarannya baik. Alasan utama manajer tingkat bawah berusaha melakukan senjangan adalah untuk meningkatkan kesempatan memperoleh penghasilan yang lebih apabila penghargaan yang diberikan ditandai dengan pencapaian anggaran, maka mereka akan cenderung membangun senjangan dalam anggarannya melalui proses partisipasi (Afiani, 2011).

Penelitian Savitri dan Sawitri (2014) menyatakan bahwa penekanan anggaran mempunyai pengaruh secara signifikan dan positif terhadap senjangan anggaran. Selanjutnya penelitian yang dilakukan oleh Lau (2013) dan Irfan et al. (2016) menyatakan bahwa penekanan anggaran berpengaruh terhadap senjangan anggaran. Berdasarkan literatur dan hasil penelitian sebelumnya maka dapat dirumuskan hipotesis sebagai berikut:

$\mathrm{H}_{2}$ : Penekanan anggaran berpengaruh positif terhadap senjangan anggaran.

Pemberian bonus kepada manajer yang mencapai target anggaran akan memungkinkan timbulnya senjangan anggaran, dimana manajer yang terkait dalam penyususnan anggaran dapat menciptakan anggaran yang mudah dicapai untuk mendapatkan kompensasi ketika target anggaran tercapai. Dampak kompensasi atas target anggaran akan memotivasi manajer untuk meningkatkan kinerja dan berusaha agar target anggaran dapat dicapai dengan melakukan 
senjangan anggaran. Hal ini karena pada umumnya, bonus tidak dibayarkan kecuali jika anggaran terpenuhi. Apabila target anggaran tercapai maka manajer akan dinilai berperetasi sehingga manajer akan mendapatkan kompensasi/bonus yang semakin besar, sedangkan apabila target anggaran sulit dicapai maka kompensasi yang diberikan kepada manajer juga kecil. Oleh karena itu, para manajer yang memiliki program bonus seperti itu atau yang kinerjanya dievaluasi berdasarkan upaya pencapaian target anggaran, akan cenderung berperilaku yang kurang disukai pada akhir periode anggaran yang bermaksud untuk mendapatkan bonus tersebut sehingga menimbulkan senjangan anggaran.

Penelitian pengaruh rencana kompensasi dengan senjangan anggaran belum banyak dikaji sebelumnya. Hasil penelitian terkait dengan pengaruh rencana kompenasi dengan senjangan anggaran dilaporkan oleh Febrian (2014) bahwa rencana kompensasi mempunyai pengaruh signifikan dan positif terhadap senjangan anggaran. Berdasarkan literatur dan hasil penelitian sebelumnya maka dapat dirumuskan hipotesis sebagai berikut:

$\mathrm{H}_{3}$ : Rencana kompensasi berpengaruh positif terhadap senjangan anggaran.

\section{METODE PENELITIAN}

Pendekatan yang digunakan dalam penelitian ini adalah metode penelitian kuantitatif berbentuk asosiatif. Menurut Sugiyono (2014:13) penelitian asosiatif adalah yang penelitian yang dilakukan untuk mengetahui pengaruh variabel bebas terhadap variabel terikat. Penelitian bertujuan untuk mengkaji hubungan antara partisipasi anggaran, penekanan dan rencana kompensasi terhadap senjangan 
anggaran. Penelitian ini dilakukan pada Hotel bintang 4 di kabupaten Badung. Kerangka konsep penelitian dipaparkan pada Gambar 1.

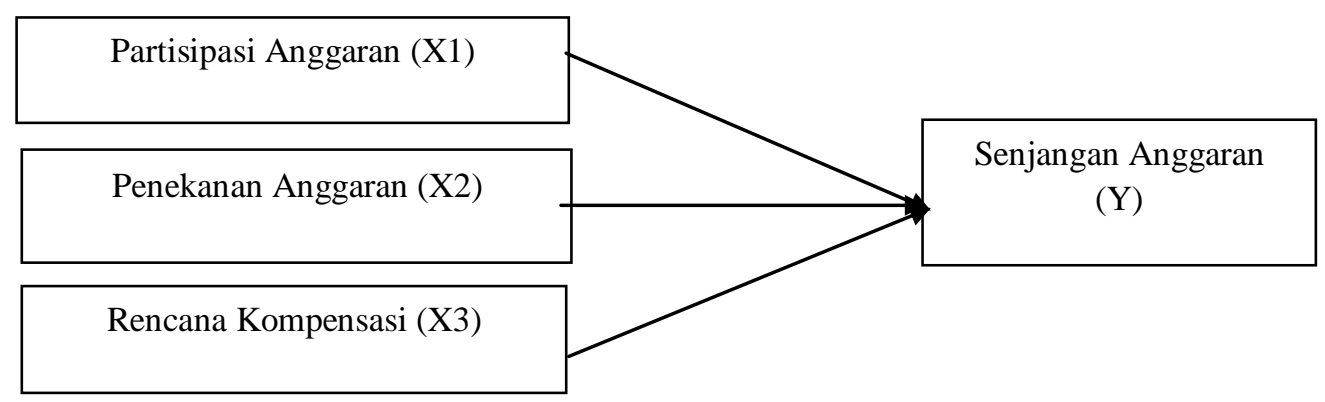
Sumber: Data diolah, 2017

\section{Gambar 1. Kerangka konsep penelitian}

Variabel terikat yang digunakan dalam penelitian ini adalah senjangan anggaran (Y). Senjangan anggaran didefinisikan sebagai kecenderungan berperilaku tidak produktif dengan melebihkan biaya saat seorang pegawai mengajukan anggaran belanja. Senjangan anggaran diukur dengan menggunakan instrumen yang digunakan oleh Karsam (2013) yaitu standar anggaran, perilaku anggaran, anggaran ketat, tekanan anggaran, efisiensi anggaran dan target anggaran.

Variabel bebas dalam penelitian ini adalah Partisipasi anggaran $\left(\mathrm{X}_{1}\right)$, Penekanan anggaran $\left(\mathrm{X}_{2}\right)$ dan Rencana kompensasi $\left(\mathrm{X}_{3}\right)$. Partisipasi anggaran diukur bberdasarkan instrumen yang dikembangkan oleh Milani (1975) yaitu keterlibatan manajer, alasan atasan merevisi anggaran, frekuensi pemberian usulan, pengaruh manajer dalam anggaran akhir, pentingnya kontribusi yang diberikan dan frekuensi penyampaian pendapat.

Penekanan anggaran diukur dengan instrumen Hoopwood (1972) yang terdiri atas enam item yaitu anggaran sebagai alat pengendali kinerja, anggaran sebagai tolak ukur kinerja, anggaran sebagai target kerja, penghargaan diberikan 
ketika mencapai target anggaran dan bonus diberikan ketika mencapai target anggaran. Rencana kompensasi diukur melalui tujuh pertanyaan (Onsi, 1973) yaitu penghasilan sepadan dengan kontribusi kerja, bonus diberikan jika bekerja sesuai target, tunjangan di luar gaji sesuai harapan, komisi diberikan sesuai harapan, penghargaan membuat semangan bekerja, kompensasi didapatkan jika kinerja baik dan pengakuan diri didapatkan berdasarkan capaian hasil kerja.

Jenis data yang digunakan dalam penelitian ini adalah data kualitatif dan kuantitatif. Data kuantitatif yang digunakan dalam penelitian ini adalah laporan anggaran dan laporan keuangan hotel bintang 4 di Kabupaten Badung, serta hasil penyebaran kuisioner yang telah dikuantitatifkan. Data kualitatif dalam penelitian ini berupa data yang diperoleh dari perusahaan secara tertulis maupun lisan mengenai gambaran umum perusahaan, sejarah berdirinya perusahaan dan kebijakan dalam penetapan anggaran pada hotel bintang 4 di Kabupaten Badung.

Sumber data yang digunakan adalah data primer dan sekunder. Data primer dalam penelitian ini berupa hasil observasi langsung dan hasil survei terkait dengan variabel partisipasi anggaran, penekanan anggaran, rencana kompensasi dan senjangan anggaran pada hotel bintang 4 di Kabupaten Badung. Data sekunder yang digunakan dalam penelitian ini adalah data laporan keuangan, profil perusahaan, nama dan status karyawan dan jurnal-jurnal terkait dengan senjangan anggaran pada hotel bintang 4 di Kabupaten Badung, yang di dapatkan dari BPS Provinsi Bali tahun 2017.

Populasi dalam penelitian ini yaitu seluruh manajer di Hotel bintang 4 di Kabupaten Badung, yang berjumlah 62 hotel (BPS Provinsi Bali, 2017). Hal ini 
disebabkan oleh pihak-pihak tersebut yang terlibat dalam penyusunan anggaran dan dibebani dengan target anggaran. Penelitian ini menggunakan teknik nonprobability sampling yaitu teknik pengambilan sampel yang tidak memberikan peluang atau kesempatan yang sama bagi setiap anggota populasi. Teknik pengambilan sampel yang digunakan berupa sampling pertimbangan (Purposive sampling) yaitu teknik untuk menentukan sampel dari populasi tertentu berdasarkan pertimbangan-pertimbangan tertentu dari peneliti untuk tujuan tertentu.

Kriteria pengambilan smapel dalam penelitian ini yaitu para manajer yang memenuhi kriteria telah menduduki jabatan sebagai department head (manajer menengah) yang terlibat dalam penyusunan dan pelaksanaan anggaran selama minimal satu tahun di seluruh Hotel bintang 4 di Kabupaten Badung. Hal ini disebabkan karena pihak-pihak tersebut yang terlibat dalam penyusunan anggaran dan dibebani dengan target anggaran, memiliki pengalaman dalam menyusun anggaran yang menjadi tanggung jawabnya, dan telah memiliki pengalaman dalam melaksanakan anggaran yang disusunnya. Di Kabupaten Badung terdapat 62 hotel Bintang 4, dimana dari masing-masing hotel akan di sampling 5 orang yang terdiri dari manajer akunting, manajer pemasaran, manajer room devisi, manajer front office dan engeenering, jadi total populasi yang akan di Slovin adalah sebanyak 310 responden. Berdasarkan rumus Slovin dengan nilai kritis 10 persen maka di peroleh banyaknya sampel yang digunakan adalah sebanyak 76 orang responden. Adapun perhitungan Slovin menurut Umar Husein (2008:78), yaitu sebagai berikut. 


$$
\begin{aligned}
& \mathrm{n}=\frac{310}{\left(1+310(0,1)^{2}\right)} \\
& \mathrm{n}=75,609 \\
& \mathrm{n}=76 \text { (dibulatkan). }
\end{aligned}
$$

Metode pengumpulan data yang digunakan dalam penelitian ini yaitu observasi, survei dan studi dokumentasi. Observasi dilakukan untuk memperoleh data primer berupa perilaku karyawan dalam hal penetapan anggaran diamati melalui observasi langsung di tempat penelitian. Hasil survei terkait dengan partisipasi anggaran, penekanan anggaran, rencana kompensasi dan senjangan anggaran dilakukan dengan menggunakan metode survei. Studi dokumentasi berupa laporan keuangan, sejarah perusahaan, struktur organisasi perusahaan, daftar nama karyawan, status karyawan dan jurnal-jurnal terkait diperoleh melalui studi dokumentasi.

Teknik analisis data yang digunakan untuk memecahkan permasalahan yang terdapat dalam penelitian ini adalah analisis regresi linear berganda. Regresi linier berganda bertujuan untuk mengetahui hubungan fungsional antara variabel independen secara bersama-sama terhadap variabel dependen. Bentuk persamaan regresi linier berganda (multiple linear regression) menurut Nugroho (2011: 92), sebagai berikut:

$$
Y=\beta 0+\beta 1 X 1+\beta 2 X 2+\beta 3 X 3+e
$$

Keterangan:

$\mathrm{Y}=$ Senjangan anggaran

$\mathrm{X} 1=$ Partisipasi anggaran

$\mathrm{X} 2=$ Penekanan anggaran

$\mathrm{X} 3$ = Rencana kompensasi

$\beta 0=$ Konstanta

$\beta 1=$ Koefisien regresi variabel partisipasi anggaran

$\beta 2=$ Koefisien regresi variabel penekanan anggaran 
$\beta 3=$ Koefisien regresi variabel rencana kompensasi

\section{HASIL DAN PEMBAHASAN}

Penelitian ini dilakukan untuk menguji pengaruh partisipasi anggaran, penekanan anggaran dan rencana kompensasi terhadap senjangan anggaran pada Hotel Berbintang 4 di Kabupaten Badung. Data dikumpulkan dengan menyebarkan kuisioner ke 19 hotel berbintang 4 yang tersebar di Kabupaten Badung. Rincian pengembalian dan penggunaan kuisioner dalam penelitian ini di jelaskan pada Tabel 1.

\section{Tabel 1}

Perincian Pengembalian dan Penggunaan Kuisioner

\begin{tabular}{lc}
\hline \multicolumn{1}{c}{ Uraian } & Jumlah Kuisioner \\
\hline Total Kuisioner yang disebar & 76 \\
Kuisioner yang dikembalikan & 47 \\
Kuisioner yang gugur & 0 \\
Kuisioner yang digunakan & 47 \\
Tingkat Pengembalian (response rate) $=$ 47/76x 100\% & 61,84 persen \\
Tingkat penggunaan (usable respon rate) $=47 / 76 \mathrm{x} \mathrm{100 \%}$ & 61,84 persen \\
\hline Sumber: data primer diolah, 2017 &
\end{tabular}

Karakteristik responden yang diteliti meliputi jenis kelamin, usia, dan angkatan responden. Ringkasan mengenai karakteristik responden dapat dilihat pada Tabel 2.

Tabel 2.

Karakteristik Responden

\begin{tabular}{clcc}
\hline \multirow{2}{*}{ No. } & \multicolumn{1}{c}{ Karakteristik Responden } & \multicolumn{2}{c}{ Jumlah } \\
\cline { 3 - 4 } & Jenis Kelamin & (Orang) & Persentase (\%) \\
\hline & Laki-laki & 33 & 70,21 \\
& Perempuan & 14 & 29,79 \\
& Total & $\mathbf{4 7}$ & $\mathbf{1 0 0}$ \\
2. & Pendidikan & & 6,38 \\
& SMA & 3 & 93,62 \\
& D3/S1/S2/S3 & 44 & $\mathbf{1 0 0}$ \\
& Total & $\mathbf{4 7}$ & \\
\hline
\end{tabular}




\begin{tabular}{lcc}
\hline 1-3 Tahun & 25 & 53,19 \\
3-10 Tahun & 14 & 29,79 \\
$>10$ Tahun & 8 & 17,02 \\
Total & $\mathbf{4 7}$ & $\mathbf{1 0 0}$ \\
\hline
\end{tabular}
Sumber: Data diolah, 2017

Berdasarkan Tabel 2 diketahui bahwa dari 47 responden terdiri dari lakilaki sebanyak 33 orang (70,21 persen), dan perempuan sebanyak 14 orang $(29,79$ persen). Berdasarkan Tabel 2 dapat diketahui bahwa responden yang pendidikannya SMA sebanyak 3 orang (6,38 persen), dan D3/S1/S2/S3 sebanyak 44 orang $(93,62$ persen). Mayoritas responden dari penelitian ini berpendidikan D3/S1/S2/S3. Berdasarkan Tabel 2, diketahui bahwa responden yang telah bekerja selama 1-3 tahun sebanyak 25 orang (53,19 persen), yang bekerja 3-10 tahun sebanyak 14 orang $(29,79$ persen) dan $>5$ tahun sebanyak 8 orang (17.02 persen). Mayoritas responden dari penelitian ini cukup berpengalamanan dalam bekerja.

Pengujian berikutnya adalah uji instrumen penelitian yang terdiri dari uji validitas dan reliabilitas. Uji validitas merupakan pengujian instrumen penelitian sebagai suatu derajat ketepatan alat ukur penelitian tentang inti atau arti sebenarnya yang diukur. Hasil uji validitas pada Tabel 3 menunjukkan bahwa seluruh variabel memiliki nilai koefisien korelasi dengan skor total seluruh item pernyataan lebih besar dari 0,30. Hal ini menunjukkan bahwa butir-butir pernyataan seluruhnya dalam instrument penelitian tersebut valid. 
Tabel 3.

Hasil Uji Validitas

\begin{tabular}{lccc}
\hline \multicolumn{1}{c}{ Variabel } & Indikator & Koefisien Korelasi & Keterangan \\
\hline Senjangan Anggaran & $\mathrm{Y}_{1.1}$ & 0,680 & Valid \\
$(\mathrm{Y})$ & $\mathrm{Y}_{1.2}$ & 0,687 & Valid \\
& $\mathrm{Y}_{1.3}$ & 0,662 & Valid \\
& $\mathrm{Y}_{1.4}$ & 0,683 & Valid \\
& $\mathrm{Y}_{1.5}$ & 0,700 & Valid \\
Partisipasi Anggaran & $\mathrm{Y}_{1.6}$ & 0,685 & Valid \\
$\left(\mathrm{X}_{1}\right)$ & $\mathrm{X}_{1.1}$ & 0,891 & Valid \\
& $\mathrm{X}_{1.2}$ & 0,629 & Valid \\
& $\mathrm{X}_{1.3}$ & 0,811 & Valid \\
Penekanan Anggaran & $\mathrm{X}_{1.4}$ & 0,636 & Valid \\
$\left(\mathrm{X}_{2}\right)$ & $\mathrm{X}_{1.5}$ & 0,714 & Valid \\
& $\mathrm{X}_{2.1}$ & 0,743 & Valid \\
& $\mathrm{X}_{2.2}$ & 0,855 & Valid \\
& $\mathrm{X}_{2.3}$ & 0,787 & Valid \\
Rencana & $\mathrm{X}_{2.4}$ & 0,855 & Valid \\
Kompensasi $\left(\mathrm{X}_{3}\right)$ & $\mathrm{X}_{2.5}$ & 0,676 & Valid \\
& $\mathrm{X}_{3.1}$ & 0,680 & Valid \\
& $\mathrm{X}_{3.2}$ & 0,687 & Valid \\
& $\mathrm{X}_{3.3}$ & 0,624 & Valid \\
& $\mathrm{X}_{3.4}$ & 0,683 & Valid \\
& $\mathrm{X}_{3.5}$ & 0,700 & Valid \\
& $\mathrm{X}_{3.6}$ & 0,605 & Valid \\
& $\mathrm{X}_{3.7}$ & 0,716 & Valid \\
\hline
\end{tabular}

Sumber: Hasil Olahan SPSS, 2017

Reliabilitas adalah derajat ketepatan, ketelitian atau keakuratan yang ditunjukkan oleh instrument pengukuran dimana pengujiannya dapat dilakukan secara internal, yaitu pengujian dengan menganalisis konsistensi butir-butir yang ada. Suatu instrument dikatakan reliabel, jika instrument tersebut memiliki nilai Alpha Cronbach lebih dari 0,60. Adapun hasil dari uji realibilitas dapat ditunjukkan pada Tabel 4.

Tabel 4.

Hasil Uji Reliabilitas

\begin{tabular}{lcc}
\hline Variabel & Cronbach's Alpha & Keterangan \\
\hline Partisipasi Anggaran $\left(\mathrm{X}_{1}\right)$ & 0,800 & Reliabel \\
Penekanan Anggaran $\left(\mathrm{X}_{2}\right)$ & 0,802 & Reliabel \\
Rencana Kompensasi $\left(\mathrm{X}_{3}\right)$ & 0,739 & Reliabel \\
Senjangan Anggaran $(\mathrm{Y})$ & 0,687 & Reliabel \\
\hline
\end{tabular}

Sumber: Hasil Olahan SPSS, 2017 
Hasil uji reliabilitas yang disajikan dalam Tabel 4 menunjukkan bahwa seluruh instrumen penelitian yaitu pertisipasi anggaran, penekanan anggaran, rencana kompensasi dan senjanagan anggaran memiliki koefisien Cronbach's Alpha lebih dari 0,60. Hal ini dapat dikatakan bahwa semua instrumen reliabel sehingga dapat digunakan untuk melakukan penelitian.

Analisis statistik deskriptif memberikan gambaran atau deskripsi suatu data yang dilihat dari besarnya nilai minimum, maksimum, mean, dan simpangan baku (standard deviation) dengan $\mathrm{N}$ merupakan banyaknya responden penelitian. Hasil analisis statistik deskriptif dapat dilihat dalam Tabel 5.

Tabel 5.

Statistik Deskriptif

\begin{tabular}{lrrrrr|}
\hline & N & \multicolumn{1}{c}{ Minimum } & Maximum & Mean & Std. Deviation \\
\hline partisipasi anggaran & 47 & 14 & 20 & 3,480 & 2,006 \\
penekanan anggaran & 47 & 12 & 20 & 3,289 & 2,215 \\
rencana kompensasi & 47 & 18 & 27 & 3,094 & 2,041 \\
senjangan anggaran & 47 & 13 & 20 & 2,965 & 1,587 \\
\hline Sumber: Hasil Olahan SPSS, 2017 & & & & &
\end{tabular}

Statistik deskriptif pada Tabel 5 menunjukkan bahwa nilai minimum dan maksimum variabel partisipasi anggaran (X1) sebesar 14,00 dan 20,00. Rataratanya (mean) sebesar 3,480 dengan standar deviasi sebesar 2,006, hal ini berarti bahwa terjadi perbedaan nilai partisipasi anggaran yang diteliti terhadap nilai rataratannya sebesar 2,006. Nilai minimum dan maksimum variabel penekanan anggaran (X2) sebesar 12,00 dan 20,00. Rata-ratanya (mean) sebesar 3,289 dengan standar deviasi sebesar 2,215, hal ini berarti bahwa terjadi perbedaan nilai penekanan anggaran yang diteliti terhadap nilai rata-ratannya sebesar 2,215.

Nilai minimum dan maksimum variabel rencana kompensasi (X3) sebesar 18,00 dan 27,00. Rata-ratanya (mean) sebesar 3,094 dengan standar deviasi 
sebesar 2,041, hal ini berarti bahwa terjadi perbedaan nilai rencana penganggaran yang diteliti terhadap nilai rata-ratannya sebesar 2,041. Nilai minimum dan maksimum variabel senjangan anggaran (Y) sebesar 13,00 dan 20,00. Rataratanya (mean) sebesar 2,965 dengan standar deviasi sebesar 1,587, hal ini berarti bahwa terjadi perbedaan nilai senjangan anggaran yang diteliti terhadap nilai rataratannya sebesar 1,587 .

Pengujian selnajutnya sebelum menganalisis dengan regresi adalah uji asumsi klasik. Hasil uji asumsi klasik yang dilakukan dalam penelitian ini adalah uji normalitas, uji multikoliniearitas, dan uji heteroskedastisitas. Uji normalitas bertujuan untuk mengetahui apakah residual dari model regresi yang dibuat berdistribusi normal atau tidak. Untuk menguji apakah data yang digunakan normal atau tidak dapat dilakukan dengan menggunakan uji Kolmogorov Sminarnov. Berdasarkan Tabel 6 dapat dilihat bahwa nilai Kolmogorov Sminarnov (K-S) sebesar 0,067, sedangkan nilai Asymp. Sig. (2-tailed) sebesar 0,200. Hasil tersebut mengindikasikan bahwa model persamaan regresi tersebut berdistribusi normal karena nilai Asymp. Sig. (2-tailed) 0,094 lebih besar dari nilai alpha 0,05.

Tabel 6.

Hasil Uji Normalitas

\begin{tabular}{cc}
\hline & Unstandardized Residual \\
\hline $\mathrm{N}$ & 47 \\
Kolmogorov-Smirnov $Z$ & 0,067 \\
Asymp.Sig.(2-tailed) & 0,200 \\
\hline
\end{tabular}

Sumber: Hasil Olahan SPSS, 2017

Uji multikolinearitas bertujuan untuk menguji apakah di dalam model regresi ditemukan adanya korelasi antar variabel bebas. Berdasarkan Tabel 7 dapat dilihat bahwa nilai tolerance dan VIF dari variabel partisipasi anggaran, penekanan anggaran, rencana kompensasi dan senjangan anggaran. Nilai tersebut 
menunjukkan bahwa nilai tolerance untuk setiap variabel lebih besar dari 10 persen dan nilai VIF lebih kecil dari 10 yang berarti model persamaan regresi bebas dari multikolinearitas.

Tabel 7.

Hasil Uji Multikoleniaritas

\begin{tabular}{lcc}
\hline \multicolumn{1}{c}{ Variabel } & Tolerance & VIF \\
\hline Partisipasi Anggaran $\left(\mathrm{X}_{1}\right)$ & 0,836 & 1,196 \\
Penekanan Anggaran $\left(\mathrm{X}_{2}\right)$ & 0,893 & 1,120 \\
Rencana Kompensasi $\left(\mathrm{X}_{3}\right)$ & 0,895 & 1,117 \\
\hline Sumber: Hasil Olahan SPSS, 2017 & &
\end{tabular}

Uji heteroskedastisitas dilakukan untuk mengetahui apakah dalam model regresi terjadi ketidaksamaan varian. Uji ini dapat dianalisis melalui uji gletser dengan melihat tingkat signifikansi, jika tingkat signifikansi berada di atas 0,05 maka model regresi ini bebas dari masalah heterokedastisitas. Pada Tabel 8 dapat dilihat bahwa nilai sig. dari variabel partisipasi anggaran, penekanan anggaran dan rencana kompensasi masing-masing sebesar $0,833,0,777$ dan 0,558 . Nilai tersebut lebih besar dari 0,05 yang berarti tidak terdapat pengaruh antara variabel bebas terhadap absolute residual. Model yang dibuat tidak mengandung gejala heteroskedastisitas.

Tabel 8.

Hasil Uji Heteroskedastisitas

\begin{tabular}{ccc}
\hline Variabel & Signifikansi & Keteranagan \\
\hline Partisipasi Anggaran $\left(\mathrm{X}_{1}\right)$ & 0,833 & Bebas heteroskedastisitas \\
Penekanan Anggaran $\left(\mathrm{X}_{2}\right)$ & 0,777 & Bebas heteroskedastisitas \\
Rencana Kompensasi $\left(\mathrm{X}_{3}\right)$ & 0,558 & Bebas heteroskedastisitas \\
\hline
\end{tabular}

Sumber: Hasil Olahan SPSS, 2017

Analisis regresi linear berganda digunakan untuk mengetahui ketergantungan satu variabel terikat hanya pada satu variabel bebas dengan atau tanpa variabel moderator, serta untuk mengetahui ketergantungan satu variabel terikat pada variabel-variabel bebas. Uji ini dilakukan untuk mengetahui besarnya 
partisipasi anggaran $\left(\mathrm{X}_{1}\right)$, penekanan anggaran $\left(\mathrm{X}_{2}\right)$, dan rencana kompensasi $\left(\mathrm{X}_{3}\right)$, terhadap senjangan anggaran $(\mathrm{Y})$. Hasil uji regresi linear berganda dapat dilihat pada Tabel 9.

Tabel 9.

Hasil Analisis Regresi Linear Berganda

\begin{tabular}{|c|c|c|c|c|c|}
\hline \multirow[t]{2}{*}{ Model } & \multicolumn{2}{|c|}{ Unstandardized Coefficients } & \multirow{2}{*}{$\begin{array}{c}\text { Standardized } \\
\text { Coefficients } \\
\text { Beta }\end{array}$} & \multirow[t]{2}{*}{$\mathbf{t}$} & \multirow[t]{2}{*}{ Sig. } \\
\hline & B & Std. Error & & & \\
\hline (Constant) & 11,247 & 2,599 & & 4,328 & 0,000 \\
\hline Partisipasi Anggaran $\left(\mathrm{X}_{1}\right)$ & 0,320 & 0,111 & 0,404 & 2,871 & 0,006 \\
\hline Penekanan Anggaran $\left(\mathrm{X}_{2}\right)$ & 0,205 & 0,098 & 0,287 & 2,104 & 0,041 \\
\hline Rencana Kompensasi $\left(\mathrm{X}_{3}\right)$ & 0,111 & 0,106 & 0,343 & 1,952 & 0,047 \\
\hline Adjusted R Square & 0,538 & & & & \\
\hline F Statistik & 5,778 & & & & \\
\hline Signifikansi & 0,002 & & & & \\
\hline
\end{tabular}

Sumber: Hasil Olahan SPSS, 2017

Berdasarkan hasil analisis regresi linier berganda seperti yang disajikan pada Tabel 9, maka persamaan regresinya adalah sebagai berikut.

$$
\mathrm{Y}=11,247+0,320 \mathrm{X} 1+0,205 \mathrm{X} 2+0,111 \mathrm{X} 3+\mathrm{e}
$$

Nilai konstanta sebesar 11,247; berarti apabila partisipasi anggaran $\left(\mathrm{X}_{1}\right)$, penenkanan anggaran $\left(\mathrm{X}_{2}\right)$, dan rencana kompensasi $\left(\mathrm{X}_{3}\right)$, bernilai 0 , maka senjangan anggaran meningkat sebesar 11,247 satuan. Nilai koefisien regresi partisipasi anggaran $\left(\mathrm{X}_{1}\right)$ sebesar 0,320 , berarti jika partisipasi anggaran meningkat 1 satuan maka senjangan anggaran akan meningkat 0,320 satuan, dengan asumsi variabel penekanan anggaran dan rencana kompensasi konstan. Hasil ini menigindikasikan bahwa partisipasi anggaran berbanding lurus dengan senjangan anggaran.

Nilai koefisien regresi penekanan anggaran $\left(\mathrm{X}_{2}\right)$ sebesar 0,205 , berarti jika penekanan anggaran meningkat 1 satuan maka senjangan anggaran akan meningkat 0,205 satuan, dengan asumsi variabel partisipasi anggaran dan rencana 
kompensasi konstan. Hal ini menunjukan bahwa ketika penekanan anggaran semakin baik maka senjangan anggaran cenderung baik pula. Nilai koefisien regresi rencana kompensasi $\left(\mathrm{X}_{3}\right)$ sebesar 0,111 , berarti jika rencana kompensasi meningkat 1 satuan maka senjangan anggaran akan meningkat 0,111 satuan, dengan asumsi variabel partisipasi anggaran dan penekanan anggaran konstan. Hal ini menunjukan bahwa bahwa rencana kommpensasi berbanding lurus dengan senjangan anggaran.

Sebelum dilakukan pengujian hipotesis, satu hal yang perlu diperhatikan adalah kelayakan model penelitian yang dilakukan dengan uji $\mathrm{F}$ untuk mengetahui pengaruh variabel-variabel independen pada variabel dependen. Nilai F hitung sebesar 5,778 dengan signifikansi 0,002 yang probabilitas signifikan lebih kecil dari alpha 0,05 . Ini menunjukan model yang digunakan pada penelitian ini adalah layak. Partisipasi anggaran, penekanan anggaran dan rencana kompensasi dapat digunakan untuk memprediksi senjangan anggaran atau dapat dikatakan bahwa partisipasi anggaran, penekanan anggaran dan rencana kompensasi secara bersama-sama berpengaruh terhadap senjangan anggaran. Nilai Adjusted R Square sebesar 0,538 mempunyai arti bahwa sebesar 53,80 persen variasi senjangan anggaran dipengaruhi oleh variasi partisipasi anggaran, penekanan anggaran dan rencana kompensasi, sedangkan sisanya sebesar 46,20 persen djelaskan oleh faktor lain yang tidak dimasukkan ke dalam model.

Berdasarkan dari hasil pengujian yang ditunjukan Tabel 9 diketahui bahwa tingkat signifikan t sebesar 0,006 yang berarti lebih kecil atau dibawah nilai $\alpha=$ 0,05. Hal ini menunjukan bahwa partisipasi anggaran berpengaruh secara positif 
signifikan terhadap senjangan anggaran. Hal ini berarti adanya pengaruh antara partisipasi anggaran dngan senjangan anggaran, bahwa semakin banyak pihak yang berpartisipasi dalam menentukan anggaran cenderung dapat meningkatkan timbulnya senjangan anggaran.

Hasil penelitian ini sesuai dengan Agency Theory yang menjelaskan fenomena apabila direktur mendelegasikan wewenang kepada manajer untuk bertanggung jawab melakukan tugas dan membuat keputusan. Masalah yang sering muncul dari adanya keterlibatan manajer tingkat bawah atau menengah dalam penyusunan anggaran adalah timbulnya senjangan anggaran. Hal ini manajer yang ikut berpartisipasi dalam penyusunan anggaran memberikan informasi yang bias kepada direktur, padahal manajer memiliki informasi yang dapat digunakan untuk membantu keakuratan anggaran perusahaan. Manajer meninggikan pengeluaran atau menurunkan pendapatan dari yang seharusnya, supaya anggaran mudah dicapai. Tingginya keterlibatan manajer dalam melakukan penyusunan anggaran akan memicu manajer melakukan tindakan yang ingin dicapai dengan menciptakan senjangan anggaran.

Lebih lanjut Raghunandan et al. (2012) juga berpendapat bahwa partisipasi anggaran mengakibatkan timbulnya Perilaku individu positif yaitu adanya peningkatan kinerja atas dorongan motivasi oleh penghargaan (reward) yang diberikan perusahaan apabila tercapainya suatu target anggaran. Sedangkan perilaku negatif yang mungkin terjadi yaitu terciptanya kesenjangan anggaran. Upaya manajer untuk mencari cara melindungi diri dari resiko yang mengakibatkan tidak tercapainya target anggaran. Bagi manajer yang tidak 
mampu mencapai target anggaran tersebut, akan menghadapi tekanan dari manajemen pada tingkat yang lebih tinggi, seperti: kehilangan bonus, kepercayaan, bahkan kehilangan pekerjaan. Untuk menghindari resiko tersebut pihak bawahan akan menciptakan senjangan anggaran. Hasil penelitian ini sesuai dengan penelitian Febrian (2014) dan penelitian Erina dan Suartana (2016) memberikan hasil bahwa partisipasi anggaran mempunyai pengaruh positif terhadap senjangan anggaran.

Berdasarkan dari hasil pengujian yang ditunjukan Tabel 9 diketahui bahwa tingkat signifikan $\mathrm{t}$ sebesar 0,041 yang berarti lebih kecil atau dibawah nilai $\alpha=$ 0,05. Hal ini menunjukan bahwa penekanan anggaran berpengaruh secara positif signifikan pada senjangan anggaran. Hal ini terjadi karena apabila kinerja manajer sangat ditentukan oleh anggaran yang telah disusun, maka manajer akan berusaha memperoleh variance yang menguntungkan. Variance yang menguntungkan tersebut diperoleh dengan cara menciptakan Slack (Raudhiah, 2014).

Terjadinya penekanan anggaran yang diterapkan dalam perusahaan akan memicu terjadinya upaya manajer untuk melakukan senjangan anggaran agar anggaran yang telah disusun mudah dicapai dengan cara melonggarkan anggaran. Manajer berusaha memperoleh perbedaan yang menguntungkan dengan cara menciptakan senjangan anggaran untuk mencapai target anggaran. Perusahaan yang menggunakan anggaran sebagai satu-satunya pengukur kinerja manajemen, yaitu berdasarkan tercapai atau tidaknya target anggaran akan mendorong manajer untuk menciptakan senjangan dengan tujuan meningkatkan prospek kompensasi ke depan. Dengan demikian, jika anggaran dijadikan tolak ukur untuk menilai 
kinerja bawahan, maka akan memicu tindakan bawahan untuk melakukan senjangan anggaran. Dengan tujuan agar anggaran yang ditetapkan mudah dicapai, sehingga bawahan memperoleh penghargaan jika kinerja bawahan ditandai dengan pencapaian anggaran. Alasan utama manajer tingkat bawah berusaha melakukan senjangan adalah untuk meningkatkan kesempatan memperoleh penghasilan yang lebih apabila penghargaan yang diberikan ditandai dengan pencapaian anggaran, maka mereka akan cenderung membangun senjangan dalam anggarannya melalui proses partisipasi.

Hasil penelitian ini sesuai dengan penelitian terdahulu yang dilakukan Savitri dan Sawitri (2014), Erina dan Suartana (2016), dan Afiani (2011) menyatakan bahwa penekanan anggaran mempunyai pengaruh secara signifikan dan positif terhadap senjangan anggaran. Selain itu hasil penelitian ini juga sejalan dengan penelitian Karsam (2015) yang menemukan bahwa penekanan anggaran yang diterapkan dalam perusahaan akan memicu terjadinya upaya manajer untuk melakukan senjangan anggaran agar anggaran yang telah disusun mudah dicapai dengan cara melonggarkan anggaran.

Berdasarkan dari hasil pengujian yang ditunjukan Tabel 9 diketahui bahwa tingkat signifikan $\mathrm{t}$ sebesar 0,046 yang berarti lebih kecil atau dibawah nilai $\alpha=$ 0,05. Hal ini menunjukan bahwa rencana kompensasi berpengaruh positif signifikan pada senjangan anggaran. Hal ini terjadi karena pemberian kompensasi atas target anggaran akan memotivasi manajer untuk meningkatkan kinerja dan berusaha agar target anggaran dapat dicapai dengan melakukan senjangan anggaran. Hal ini karena pada umumnya, bonus tidak dibayarkan kecuali jika 
anggaran terpenuhi. Apabila target anggaran tercapai maka manajer akan dinilai berperetasi sehingga manajer akan mendapatkan kompensasi/bonus yang semakin besar, sedangkan apabila target anggaran sulit dicapai maka kompensasi yang diberikan kepada manajer juga kecil. Oleh karena itu, para manajer yang memiliki program bonus seperti itu atau yang kinerjanya dievaluasi berdasarkan upaya pencapaian target anggaran, akan cenderung berperilaku yang kurang disukai pada akhir periode anggaran yang bermaksud untuk mendapatkan bonus tersebut sehingga menimbulkan senjangan anggaran.

Hasil penelitian ini sesuai dengan penelitian Raghunandan, et al. (2012) menyatakan bahwa pemberian bonus kepada bawahan yang mencapai target anggaran akan memungkinkan timbulnya senjangan anggaran, dimana bawahan menciptakan anggaran yang mudah dicapai untuk mendapatkan kompensasi ketika target anggaran tercapai. Selain itu hasil penelitian ini juga didukung oleh Febrian (2014) bahwa rencana kompensasi mempunyai pengaruh signifikan dan positif terhadap senjangan anggaran.

\section{SIMPULAN}

Berdasarkan hasil analisis dapat disimpulkan bahwa partisipasi anggaran berpengaruh positif dan signifikan pada senjangan anggaran. Artinya, meningkatnya partisipasi dalam penentuan anggaran, maka cenderung akan meningkatkan terjadinya senjangan anggaran. Penekanan anggaran berpengaruh positif dan signifikan pada senjangan anggaran. Artinya, semakin tinggi penekanan terhadap anggaran yang ditergetkan, maka cendrung dapat meningkatkan terjadinya senjangan anggaran. Rencana kompensasi berpengaruh 
positif dan signifikan pada senjangan anggaran. Artinya, semakin tinggi tingkat kompensasi yang ditaergetkan, maka cendrung dapat meningkatkan terjadinya senjangan anggaran.

Saran yang dapat diberikan berdasarkan hasil analisis adalah bagi pemilik perusahaan (principal) harus lebih memerhatikan partisipasi dari para manajer dalam perumusan anggaran dengan cara mengkaji ulang (review) rancangan anggaran yang telah dibuat oleh para manajer bawahan sebelum rancangan anggaran tersebut diberlakukan. Hal ini dilakukan agar senjangan anggaran yang terjadi dapat diminimalkan dan anggaran yang ditetapkan sesuai dengan kemampuan sesungguhnya dari para manajer. Dalam penyusunana anggaran pemilik (owner) dengan manajer yang terlibat sebaiknya memperhatikan tingkat pencapaian dari anggaran tahun sebelumnya dan menganalisa kenaikan anggaran yang dibuat dengan rasio kenaikan anggaran yang masuk akal, sehingga diperoleh susunan anggaran yang tepat dan senjangan angaran dapat diminimalisasi.

\section{REFERENSI}

Afiani, D.N. 2011 Pengaruh Partisipasi Anggaran, Penekanan Anggaran, dan Asimetri Informasi Terhadap Senjangan Anggaran. Skripsi Program Sarjana Fakultas Ekonomi Universitas Diponegoro, Semarang.

Apriyandi. 2011. Pengaruh Informasi asimetri terhadap hubungan antara anggaran partisipasi dengan budgetary slack. Skripsi Fakultas Ekonomi dan Bisnis universitas Hasanudin, Makassar.

Beuren, I.M., Beck, F., dan Popik, F. 2015. Do shared interest affect the accuracy of budgets?. Revista contabilidade and financas, 26(67).

Daft, Richard. 2000. Manajemen. Edisi kelima. Jilid Satu. Jakarta: PT Gelora Aksara Pratama (Erlangga). 
Damrongsukniwat, P., Kunpanitchakit, D., dan Durongwatana, S. 2015. The measurement of budgetary slack: the empirical evidence of listed companies in thailand. Journal of economics, business and management, 3(2), pp: 244-251.

Dunk, A.S. 1993. The effect of budget emphasis and information asymetry on the relation between budgetary partisipation and slack. Dalam International Journal of Applied Finance and Business Studies, 1(1), pp: 28-38.

Erina, N.P.D., dan Suartana, W. 2016. Pengaruh partisipasi penganggaran, penekanan anggaran, kapasitas individu, dan kejelasan sasaran anggaran pada senjangan anggaran. E-jurnal Akuntansi Universitas Udayana, 15(2), pp: 973-1000.

Erni Aprianti, Ni Kadek., I Made Pradana A., dan Edy Sujana. 2014. Pengaruh Partisipasi Anggaran terhdap Senjangan Anggarran dengan Penekanan Anggaran dan Komitmen Organisasi sebagai Variabel Moderasi. E-Jurnal Akuntansi Universitas Ganesha, 2(1).

Febrian, Y.A. 2014. Pengaruh partisipasi anggaran, penekanan anggaran, kompensasi dan senajangan anggaran di perusahaan manufaktur. Skripsi Jurusan Akuntansi Universitas Kristen Satya Wacana, Salatiga.

Hopwood, A.G. 1972. An Empirical Study of The Role Accounting Data in Performance Evaluation. Journal of Accounting Research (Supplement 1972). pp 156-182.

Irfan, M., Santoso, B., dan Effendi, L. 2016. Pengaruh partisipasi anggaran terhadap senjangan anggaran dengan asimetri informasi, penekanan anggaran dan komitmen organiasional sebagai variabel pemoderasi. Jurnal akuntansi dan Investasi, 17(2), pp: 158-175.

Jensen, M.C., dan Mecklin, W.H. 1976. Theory of the film: managerial behaviour, agency cost, and ownership structure. Jurnal Akuntansi, 2(2), pp: 210-226.

Karsam. 2013. The Influence of Participation in Budgeting on Budgetary Slack with Information Asymetry as a Moderating Variable and Its Impact on the Managerial Performance (A Study on Yayasan Pendidikan dan Koperasi in the Province of Banten, Indonesia). International Journal of Applied Finance and Business Studies, 1(1), pp: 28-38.

Karsam. 2015. Pengaruh penekanan anggaran dan motivai terhadap hubungan antara partisipasi anggaran dengan senjangan anggaran serta dampaknya pada kinerja manajerial. Jurnal Dinamika Akuntansi dan Bisnis, 2(1), pp: 29-44. 
Lau. 2013. The interactive effect of emphasis on tigh budget targets and cost control on performance and slack creation. Thesis Faculty of Business Edith Cowan University, Western Australia, pp: 10.

Lukka, K. 1988. Budgetary Biasing in Organizations: Theoritical Frame Work and Empirical Evidence. Accounting Organization and Society 13, PP. 281301.

Maiga, A.S., Nilsson, A., dan Jacobs, F.A. 2014. Assessing the impact of budgetary participation on budgetary outcomes: the role of information technology for enhanced communication and activity-based costing. International journal of Accounting , 22 Agustus 2014.

Merchant Kenneth A, 1985. Budgeting and Prospersity to Create Budgetary Slack. Journal of Accounting, Organization, and Society. 10(1): pp: 201210.

Milani, K. 1975. The Relationship of Partisipation in Budget Setting to Industrial Supervisor Performance and Attitude: A Field Study. The Accounting Review, 50, pp: 274-278.

Nawastri, S. 2015. Analisis faktor-faktor yang berpengaruh terhadap efektivitas penerapan anggaran berbasis kinerja. Skripsi Fakultas Ekonomika dan Bisnis Universitas Diponegoro, Semarang.

Nugroho, Y.A. 2011. It's Easy... Olah Data dengan SPSS. Yogyakarta: Skripta Media Creative.

Nouri, H. 1994. Using Organizational Commitment and Job Involvement to Predict Budgetary Slack: A Research Note. Journal of Accounting, Organization and Society. No. 3. pp: 289-295.

Onsi, M. 1973. Factor Analysis of Behavioural Variables Affecting Budgetary Slack. The Accounting Review, 48(3), pp: 535-548.

Raghunandan, M.,Narendra Ramgulam, and Kishina Raghunandan Mohammed, 2012, Examining the behavioural Aspects of Budgeting with Particular Empasis on Public Sector/Service, International Journal of Business and Social Science, Vol. 3, No. 14, Hal. 110-117.

Rahman, Firdaus Abdul dan Bambang Supomo. 2003. Pengaruh Partisipasi Anggaran dan Keterlibatan Kerja terhadap Senjangan Anggaran dengan Komitmen Organisasi sebagai Variabel Moderating. Jurnal Bisnis dan Akuntansi. Vol.5(2).127-146. 
Raudhiah N. 2014. Impact of Organisasional Factors on Budgetary Slack. Disampaikan dalam E-proceeding of the Conference on Management and Muamalah Universitas Kebangsaan Malaysia, Malaysia, 26-27 Mei 2014.

Savitri, E., dan Sawitri, E. 2014. Pengaruh partisipasi anggaran, penekanan anggaran, dan informasi asimetri terhadap timbulnya kesenjangan anggaran. Jurnal Akuntansi, 2(2), pp: 210-226.

Widanaputra, A.A., dan Mimba, N.P.S.H. 2014. The influence of participative budgeting on budgetary slack in composing local governments' budget in Bali province. Procedia - Social and Behavioral Sciences, 164, pp: 391 396, International Conference on Accounting Studies 2014, ICAS 2014, 18-19 August 2014, Kuala Lumpur, Malaysia.

Young, M.S., 1985, Participative Budgeting : The effects of Risk Aversion and Asymetric Information on Budgetary Slack. Journal of Accounting Research, Vol. 23, No. 2. Pp. 829-842. 